\title{
Stress Scale (Automatic Thinking): Investigating the Psychometric Properties
}

Sümeyra Dilek Uylas ${ }^{1}$
Nihan Arslan ${ }^{2}$

\begin{abstract}
The aim of the study is to investigate the psychometric properties of Stress Scale (Automatic Thinking). Quantitative research methods was used in the study. The purpose of the research is to adapt the Stress Scale (Automatic Thinking) developed by Gordon L. Flett, Paul L. Hewitt and Taryn Nepo into Turkish culture. The research was implemented on 219 university students. The uni-dimensional model which was consisted of 7 items was found coherent in the confirmatory and exploratory factor analysis. Internal consistency, item and factor analysis studies were conducted to examine psychometric properties of the scale. It was found that Cronbach Alfa coefficient is .81 as a result of reliability analysis. As a result of exploratory factor analysis, the Kaiser-Meyer-Olkin sample adequacy value of the scale was .828; it was concluded that uni- dimensional scale explained $47 \%$ of variance.
\end{abstract}

Keywords: Stress, validity, reliability

\section{Introduction}

Stress, expressed as the disease of modern society, is essentially a part of our daily life. Today, many people are under intense stress even if they do not notice. No matter what is good or bad, mental changes in human life cause stress. Anything that can cause a change in routine life is stressful (Güçlü, 2001). It is known that there are many reasons for individuals to experience stress. The factors that cause stress are called stress sources (stressors). Stressors can cause constructive stress (eustress) or destructive stress (distress) in individuals. Stress can be beneficial to the course of life to some extent. The important thing is to catch the motivating type of stress, to avoid harmful and generally destructive stress identified with the concept of stress, to enjoy life and to increase efficiency in every field accordingly (Gürşen Otacıoğlu, 2016; Karagöz, 2016; Şahin, 2005). In addition, people have biological, psychological and social needs. When they cannot satisfy these needs adequately, they become stressed (Ravichandran, \& Rajendran, 2007). Although the concept of stress has been used quite widely for a long time, a common definition has not been made. This concept, which comes from the Latin words "estrica" and the old French "estrece", was used in the 17th century to mean disaster, trouble, fatality, nuisiance, grief, anguish (Aydın, 2008). Hals Selye (1978) defined stress as a situation in which the organism balance of the individual is threatened by internal or external sources (Ravichandran \& Rajendran, 2007). One of the general views about stress is that the vulnerability and weakness of people makes them sensitive. This vulnerability, on the other hand, triggers a significant level of life stress, especially if this stress involves themes at the core of one's self-identity (Flett et al., 2019).

\footnotetext{
1 MEB, s_dilek54@hotmail.com, ORCID: 0000-0002-5151-3733

2 Necmettin Erbakan University, nihan.arslan@erbakan.edu.tr, ORCID: 0000-0002-2451-0852
} 
We can divide the factors that cause stress in the individual into three. These are (1) the individual's selfstress sources, (2) the sources of stress arising from the work environment of the individual, (3) the sources of stress caused by the general environment in which the individual lives (Pehlivan, 1995). Individuals' self-stress sources are one of the most important factors that cause the emergence of stress. A good analysis of the individual's self-stress sources is very effective in explaining the causes of stress produced by individuals. Some of the factors that cause self-stress sources are the way people live, their behavior and their personality. Hammen (1991) stated that personal factors, which are one of the various factors that contribute to an individual's tendency to stress, are one of the most important factors affecting the level of stress production of individuals. In addition, it has been seen with the works of Hewitt and Flett (1993) that perfectionism, which is one of the personality traits, and stress are related to each other. La Rocque et al. (2016) studied perfectionism and stress and determined that stress and personality are related. Flett et al. (2019) also suggested that stress produced by individuals is the result of perfectionism and a few more factors.

With all this information, it is understood that individuals can have personality traits that may increase their stress levels, increase their stress levels by themselves and are a very effective factor in the stress production process. In short, an individual can increase his/her own stress production. Hammen argued that some people are actually responsible for some of the stress in their lives. Because people make their own behaviors and decisions. Until the work of Hammen (1991), the view that stress was an uncontrollable phenomenon and happened to people as a result of misfortune was quite common. Flett et al. (2019) developed a scale to measure the stress level produced by individuals. They considered self -criticism as an important element and focus. Because those who accept their role in stress production can be harsh against themselves during the self-criticism process. The scale was developed in order to determine to what extent chronic stress, distress and dysfunctions (personality disorder, addiction, nonsuicide self-harm, etc.) affect the stress level of the person. The aim of the study is to examine the psychometric properties of the Stress Scale (Automatic Thinking).

\section{Method}

In order to adapt the Stress Scale (Automatic Thinking) developed by Gordon L. Flett, Paul L. Hewitt and Taryn Nepo into Turkish culture, the authors were contacted via e-mail and necessary permission was obtained to adapt the scale. First of all, the scale was translated into Turkish by 3 faculty members working in the department of Psychological Counseling and Guidance, and then these Turkish forms were translated back to English and the consistency between the two forms was examined. The same faculty members discussed the Turkish forms they obtained and made the necessary corrections in terms of grammar and meaning, and the Turkish form for the pilot scheme was obtained. The research was carried out on 219 university students. 


\section{Findings}

\section{Reliability}

The internal consistency reliability coefficient of the Stress Scale (Automatic Thinking) was found to be .81. As a result of the analysis, it was observed that the adjusted item-total correlations of the Stress Scale (Automatic Thinking) ranged between .45 and .66. The coefficients of the adjusted item-total correlations of the scale are shown in Table 1. As a result of exploratory factor analysis, the Kaiser-Meyer-Olkin sample adequacy value of the scale was . 828 , it was concluded that uni-dimensional scale explained $47 \%$ of variance.

\section{Table 1}

Correlation Scores of Stress Scale (Automatic Thinking) Items

\begin{tabular}{ll}
\hline Item No & $r j x$ \\
\hline 1 & .58 \\
2 & .54 \\
3 & .45 \\
4 & .50 \\
5 & .66 \\
6 & .53 \\
7 & .54 \\
\hline
\end{tabular}

\section{Construct Validity}

Confirmatory factor analysis: For the structural validity of the Stress Scale (Automatic Thinking), CFA was applied to confirm the factors in the original form of the scale. In the CFA, the fit indices of the model were examined, and it was seen that the uni-dimensional model fits well $\left(x^{2}=57.85, \mathrm{df}=14\right.$, RMSEA $=.120, \mathrm{CFI}=.90, \mathrm{IFI}=.90, \mathrm{NFI}=.87, \mathrm{NNFI}=.85 \mathrm{AGFI}=.86$, and $\mathrm{SRMR}=.087)$. Factor loads for the model are shown in Figure 1. 


\section{Figure 2}

\section{Confirmatory Factor Analysis}

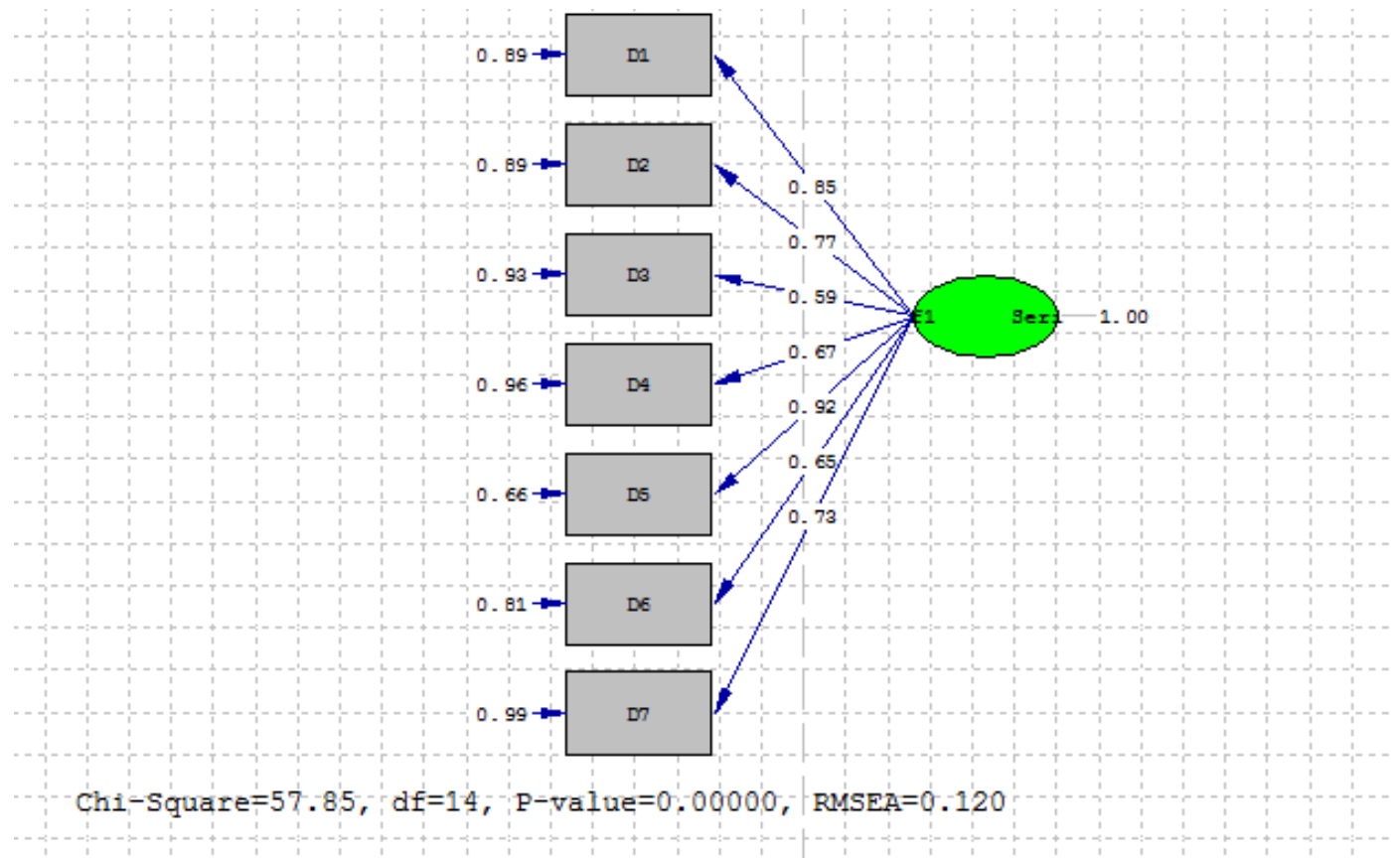

\section{Discussion}

In this study, it was aimed to adapt the Stress Scale (Automatic Thinking) developed by Gordon L. Flett, Paul L. Hewitt and Taryn Nepo to Turkish culture and to examine the validity and reliability of the Turkish form. The groups in which the validity and reliability studies are conducted are sufficient in terms of number as required by statistical analysis. The construct validity of the Stress Scale (Automatic Thinking) was examined with CFA. Considering the fit index limits for CFA, it is seen that the model fits well, and the original factor structure of the scale matches the factor structure of the Turkish form. The high reliability coefficients of the scale indicate that the reliability is at a sufficient level. The internal consistency values show that the items in the scale are consistent with each other, so the reliability in terms of internal consistency is high. Considering that the scale is a measurement tool that can only be used in research not for diagnosis or classification purposes, these coefficients are sufficient. All findings obtained from the validity and reliability studies of the scale revealed that this scale has a sufficient level of validity and reliability in order to evaluate the effects of stress and stress effects of automatic thinking on individuals. Some recommendations can be made within the framework of the findings obtained from the validity and reliability studies of the scale. The research group, in which the validity and reliability studies of the scale are conducted, consists of university students. Therefore, it would be appropriate to conduct validity and reliability studies of the scale on different samples. In addition, in order to determine the convergent validity of the scale, the connections between stress automatic thinking and other related concepts can be examined. 


\section{References}

Aydın, İ. (2008). İş yaşamında stres (3. Baskı). Ankara: Pegem Akademi Yayınları.

Flett, G. L., Hewitt, P. L. \& Nepon, T. (2019). The self-generated stress scale: Development, Psychometric features, and associations with perfectionism, self-criticism, and distress. Journal of Psychoeducational Assessment, 1-15.

Güçlü, N. (2001). Stres yönetimi. G.Ü. Gazi Eğitim Fakültesi Dergisi, 21(1), 91-109.

Gürşen Otacioğlu, Ş. (2016).Performance anxiety and academic success level examination of students in Turkey. International Journal of Educational Research Review, 1(2), 25-33.

Hammen, C. (1991). Generation of stress in the course of unipolar depression. Journal of Abnormal Psychology, 100(4), 555-561. https://doi.org/10.1037/0021-843X.100.4.555.

Hewitt, P. L., \& Flett, G. L. (1993). Dimensions of perfectionism, daily stress, and depression: A test of the specific vulnerability hypothesis. Journal of Abnormal Psychology, 102(1), 58-65. https://doi.org/10.1037/0021-843X.102.1.58.

Karagöz, Ş. (2016). Opinions and suggestions regarding various subjects on the educational guidance in the second constitutional era. Journal of Family, Counseling, and Education, 1(1), 1-9.

La Rocque, C. L., Lee, L., \& Harkness, K. L. (2016). The role of current depression symptoms in perfectionistic stress enhancement and stress generation. Journal of Social and Clinical Psychology, 35(1), 64-86.

Pehlivan, İ. (1995). Yönetimde stres kaynakları. Pegem Yayınları Personel Geliştirme Merkezi, Yayın No: 16, Ankara.

Ravichandran, R., \& Rajendran, R. (2007). Perceived sources of stress among the teachers. Journal of the Indian Academy of Applied Psychology, 33, 133-136.

Selye, H. (1974). Stress without distress. New York: J. B. Lippencott Comp. 


\section{Ek 1. Stres Ölçeği (Otomatik Düşünce)}

Her sorunun karşısında bulunan 1-Kesinlikle katılmıyorum, 2-Katılmıyorum, 3 Kararsızım, 4-Katıllyorum, 5 Kesinlikle katıllyorum anlamina gelmektedir

\begin{tabular}{|c|l|c|c|c|c|c|}
\hline 1 & Kendimi olması gerekenden daha stresli durumlara sokma alışkanlığım var. & 1 & 2 & 3 & 4 & 5 \\
\hline 2 & $\begin{array}{l}\text { Hayatımda stresle başa çıkma yollarım çoğunlukla benim daha fazla strese } \\
\text { girmem ile sonuçlanır. }\end{array}$ & 1 & 2 & 3 & 4 & 5 \\
\hline 3 & Kendimi çok fazla problem çıkaran birisi olarak görürüm. & 1 & 2 & 3 & 4 & 5 \\
\hline 4 & Karşılaştı̆̆ım stresin çoğu yaptığım seçimlerden dolayıdır. & 1 & 2 & 3 & 4 & 5 \\
\hline 5 & $\begin{array}{l}\text { Kendimi bazen stresli bir durumu çok daha kötü hale getirebilecek birisi olarak } \\
\text { görürüm. }\end{array}$ & 1 & 2 & 3 & 4 & 5 \\
\hline 6 & $\begin{array}{l}\text { Stresimin bir kısmı, belirli insanlarla ilişki kurma kararımı gösterir. } \\
7\end{array}$ & 1 & 2 & 3 & 4 & 5 \\
\hline Hatalarım işlerimin daha stresli bir hale gelmesine neden olur. & 1 & 2 & 3 & 4 & 5 \\
\hline
\end{tabular}

